\title{
Plant-animal interactions in the era of environmental DNA (eDNA) - a review
}

Pritam Banerjee ${ }^{1}$, Kathryn A. Stewart ${ }^{1}$, Caterina M. Antognazza ${ }^{1}$, Ingrid V. Bunholi ${ }^{1}$, Kristy Deiner ${ }^{1}$, Matthew A. Barnes ${ }^{1}$, Santanu Saha ${ }^{1}$, Héloïse Verdier ${ }^{1}$, Hideyuki Doi ${ }^{1}$, Jyoti Prakash Maity ${ }^{1}$, Michael W.Y. Chan ${ }^{1}$, and Chien Yen Chen ${ }^{1}$

${ }^{1}$ Affiliation not available

February 18, 2022

Pritam Banerjee ${ }^{1,2}$, Kathryn A. Stewart ${ }^{3}$, Caterina M. Antognazza ${ }^{4}$, Ingrid V. Bunholi ${ }^{5}$, Kristy Deiner ${ }^{6}$, Matthew A. Barnes ${ }^{7}$, Santanu Saha ${ }^{8}$, Hélö̈se Verdier ${ }^{9}$, Hideyuki Doi ${ }^{10}$, Jyoti Prakash Maity ${ }^{2}$, Michael W.Y. Chan $^{1}$, Chien Yen Chen ${ }^{*}$

${ }^{1}$ Department of Biomedical Sciences, Graduate Institute of Molecular Biology, National Chung Cheng University, 168 University Road, Ming-Shung, Chiayi County 62102, Taiwan

${ }^{2}$ Department of Earth and Environmental Sciences, National Chung Cheng University, 168 University Road, Ming-Shung, Chiayi County 62102, Taiwan.

${ }^{3}$ Institute of Environmental Science, Leiden University, 2333 CC Leiden, The Netherlands

${ }^{4}$ Department of Theoretical and Applied Science, University of Insubria, Via J.H. Dunant, 3, 21100, Varese, Italy

${ }^{5}$ Department of Biology, Indiana State University, Terre Haute, IN 47809, USA

${ }^{6}$ Department of Environmental Systems Science, ETH Zurich, Universitätstrasse 16, CH-8092 Zurich, Switzerland

${ }^{7}$ Department of Natural Resources Management, Texas Tech University, Lubbock, TX USA

${ }^{8}$ Post Graduate Department of Botany, Bidhannagar College, Salt Lake City, Kolkata 700064, India

${ }^{9}$ Univ Lyon, Université Claude Bernard Lyon 1, CNRS, ENTPE, UMR 5023 LEHNA, Villeurbanne, France

${ }^{10}$ Graduate School of Information Science, University of Hyogo, 7-1-28 Minatojima-minamimachi, Chuo-ku, Kobe, 650-0047, Japan

\begin{abstract}
Plant-animal interactions (PAI) represent major channels of energy transfer through ecosystems, where both positive and antagonistic interactions simultaneously contribute to ecosystem functioning. Monitoring PAI therefore increases understanding of environmental health, integrity and functioning, and studying complex interactions through accurate, cost-effective sampling can aid in the management of detrimental anthropogenic impacts. Environmental DNA (eDNA)-based monitoring represents an increasingly common, nondestructive approach for biomonitoring, which could help to elucidate PAI. Here, we focused our foundation to discuss the potential of eDNA in studying PAI on the literature existing from 2009 to 2021 using a freely accessible web search tool. The search was conducted by using key words involving eDNA and PAI, including both species-specific and metabarcoding approaches, recovering 43 studies. We summarise advantages
\end{abstract}


and current limitations of such approaches, and we offer research priorities that will potentially improve future eDNA-based methods for PAI analysis. Our review has demonstrated that numerous studies exist using eDNA to identify PAI (e.g., pollination, herbivory, mutualistic, parasitic relationships), and although eDNA-based PAI studies remain in their infancy, to date they have identified higher taxonomic diversity in several direct comparisons to DNA-based gut/bulk sampling and conventional survey methods. Research into the influencing factors of eDNA detection involved in PAI (e.g., origin and types, methodological standardization, database limitations, validation with conventional surveys, and existing ecological models) will benefit the growth of this application. Thus, implementation of eDNA methods to study PAI can particularly benefit environmental biomonitoring surveys that are imperative for biodiversity health assessments.

\section{Keywords}

Plant-animal interactions (PAI), environmental DNA (eDNA), molecular ecology, biodiversity loss, nondestructive, biodiversity sampling, conservation management, ecosystem functioning

\section{Introduction}

More than one million species are at risk of becoming threatened with extinction (IPBES, 2019), heralding the Anthropocene as the sixth mass extinction event (Myers, 1990; Román-Palacios \& Wiens, 2020). The loss of species interactions may occur well before the actual extinction of individual species, thereby initiating deleterious effects on species functionality and its service to the ecosystem (Valiente-Banuet et al., 2015). This in-turn further accelerates species extinction rates (Simmons et al., 2020), which is especially pertinent for specialist species (Colles et al., 2009). In fact, given that the loss of successive interactions provides an early warning system for the deterioration of ecosystem health (Valiente-Banuet et al., 2015), documenting, monitoring, and conserving such complex interactions is critical to retain ecosystem functioning.

One of the principal means by which taxa are interconnected in nature is via plant-animal interactions (PAI). These interactions can play pivotal ecological roles and materialize in multiple combinations of positive and antagonistic relationships (e.g. predation; frugivory and herbivory, parasitism, and mutualism). For example, frugivory contributes to propagation and thus facilitates plant restoration (Chama et al., 2013; Monge et al., 2020) and gene flow (Robledo-Arnuncio \& Garcia, 2007). Without such mutualistic relationships, some plants may not be able to complete their life cycles, and the animals may starve due to resource deficiency. Herbivory leads to defoliation or root removal, which can regulate or diminish overall phytomass, but can also increase species diversity and influence plant distribution (Milchunas \& Lauenroth, 1993; Castagneyrol et al., 2017), thereby regulating ecosystem stability (Wirth et al., 2008; Schallhart et al., 2012; Castagneyrol et al., 2017). In pollinator-plant mutualisms, the former acquires feeding from the latter, and in return serves as an agent of plant propagation and a vector for gene flow (Ellis \& Johnson, 2012). Studies documenting the food habits of pollinators and their interactive role in sustaining ecosystems have already shed light on the complex network of species-specificity, habitat preference, and co-evolution between plants and their pollinators (Sargent \& Ackerly, 2008). Mutualisms also assist with growth and offer protection from pathogens (e.g., plant- insect associations; Rasmussen et al., 2021). In contrast, antagonistic interactions (e.g., parasites, parasitoids) can affect the growth of plants and result in economical and ecological loss (Derocles et al., 2015). Thus, PAI underpin many of the fundamental processes related to ecosystem structure and functioning (Pacini et al., 2008). However, studying these multifaceted interactions using conventional methods (e.g., field observation, camera, malaise, and pitfall traps, and gut-content analysis), is often difficult and laborious (Thomsen \& Sigsgaard, 2019). Alternatively, molecular advancements with the analysis of trace DNA from environmental samples (i.e., environmental DNA or ' $\mathrm{DDNA}$ ') have provided researchers and managers the ability to scale up documentation and monitoring of such relationships, and to do so at increased spatiotemporal frequencies with more cost effectiveness (see Figure 1).

Methodological development for the application of eDNA has rapidly evolved from presence/absence detection of organisms (Ficetola et al., 2008) and abundance quantification of eDNA signals (Taberlet et al., 2012), to the detection of whole communities (Deiner et al., 2021) and even their trophic interactions (Thomsen 
\& Sigsgaard, 2019; D'Alessandro \& Mariani 2021). Indeed, eDNA-based methods have experienced a sharp adoption in different fields such as conservation biology (e.g., detection of endangered or invasive species; Piaggio et al., 2014; Stewart et al. 2017), ecological biomonitoring in terrestrial and aquatic ecosystem (e.g., environmental health monitoring; Xie et al., 2017), wildlife forensics (Allwood et al., 2020), wildlife disease monitoring (Barnes et al., 2020), and animal behaviour (Nichols et al., 2015). The application of eDNA methods to investigate a myriad of ecological interactions such as pollination (e.g., plant insects, plant-animal), predation (e.g., herbivory, frugivory), and mutualism (e.g., plant-nematode, plant-insect, plant-animals) (Thomsen \& Sigsgaard, 2019; Van Beeck Calkoen et al., 2019; Rasmussen et al., 2021) further demonstrates the application of eDNA as a multidisciplinary approach (Deiner et al., 2021; Veilleux et al., 2021) poised to tackle complex ecological questions regarding inter-taxa relationships. However, as with every newly developed method, the importance of eDNA on PAI studies remains less evaluated.

Here we review the use of eDNA-based methods to study PAI. We discuss the advantages and current limitations of such methods, and propose research priorities that may improve future eDNA-based methods for PAI analysis. Within this context, our goal is to highlight for both researchers and managers, the potential utility of non-invasive/destructive eDNA-based methods, but we also aim to identify and clarify uncertainties and next steps needed to advance these methods for broad application.

\section{Methods}

In order to understand the state-of-the-art in eDNA to study PAI and enable an effective discussion of this application, we qualitatively reviewed studies incorporating eDNA methods into PAI research (targeted and metabarcoding approaches) by searching the literature published between 2009 to 2021 using Google Scholar (https://scholar.google.com/) with the following search conditions: 1) "[eDNA] AND [plant-animal interactions]"; 2) "[eDNA] AND [pollination]"; 3) "[pollen metabarcoding]"; 4) "[eDNA] AND [herbivory]"; 5) "[herbivory metabarcoding]"; and 6) "[fecal metabarcoding]". The content of the top 100 publications on Google Scholar were verified manually. We selected papers that worked on non-destructive eDNA-based methods for representation. The selected publications were then evaluated to understand the potential advantages and limitations of eDNA-based methods in the study of PAI.

\section{Why use eDNA-based methods for studying PAI?}

Conventional methods such as field observation, histological and biochemical analysis, various camera, malaise or pitfall traps, etc., have proved their utility for identifying and expanding knowledge on PAI across numerous species groups, research questions, and intended outcomes (ecological, or evolutionary fundamental knowledge, agricultural/horticultural production, conservation management and action plans). Yet historically, most studies on PAI generally focus on pairs of species (Herrera and Pellmyr, 2009), and thus the ecologically complex interactions between species groups remain less understood (Luna \& Dattilo, 2021). Indeed, numerous animal species are interconnected with plants, they may co-exist or not, but still have potential impacts on each other across their network (Luna \& Dattilo, 2021). These interactions are dynamic processes and thus their subsequent observation is often difficult using discrete means of data collection.

In direct comparison with conventional methods for example, DNA metabarcoding has greater ability to detect closely related taxa (Macgregor et al., 2019), is time-efficient and cost-effective, whereas the application of conventional methods may be difficult for large-scale sampling. Additionally, conventional methods may be unable to resolve diverse yet morphologically conserved groups (e.g., Nematodes; Derycke et al., 2010), particularly cryptic species (Sheth and Thaker, 2017). Thus, implementation of molecular methods may help us to understand how evolutionary mechanisms shape different PAI and assemble related species. Studying PAI would therefore frequently require sampling methods that provide broad spatiotemporal inference, involving entire species groups.

Indeed, DNA-based methods offer broad output with the capability of identifying multiple PAI simultaneously, and the ease at which DNA is collected and analysed also affords multiple sampling events for an integrative approach (Evans and Kitson, 2020). More direct DNA-based methods (e.g., metabarcoding of gut contents, or bulk samples - contain several organisms from different taxonomic group together, e.g, Kick-Net 
sampling or insect trap, that amalgamate entire organisms into a single sample, Taberlet et al., 2018) have already proved useful in elucidating complex species and trophic interactions (Garcia-Robledo et al., 2013). For instance, direct DNA analysis from gut content or bulk samples have illuminated different nodes across various food webs, and reconstructed the trophic links in terrestrial (Wirta et al. 2014, 2015a, 2015b, 2016; Gogarten et al., 2020), aquatic (Leray et al., 2012; Leray et al., 2015) and often inaccessible environments, such as deep-sea beds, hydrothermal vents, and cold-seeps (Olsen et al., 2014). Several reviews to date have summarized the history, achievements, and current applications of studying species interaction using direct DNA-based methods across multiple fields (Symondson, 2002; Valentini et al., 2009; Pompanon et al., 2012; Clare, 2014; Kress et al., 2015; Evans et al., 2016). Still direct DNA-based methods with tissue, bulk, and gut content samples can be destructive in nature, sometimes requiring the sacrifice of focal organisms which is not ideal or practical for species of conservation concern. Both conventional and direct DNA based methods further (generally) focus on animal interactions with different plants, whereas the converse (plant interactions with multiple animal species) remain less understood.

Novel sampling techniques such as the collection of DNA from soil, water or air environments (eDNA) offers a method for studying PAI with the potential capability for identifying multiple PAI simultaneously, while also facilitating a conservation-friendly, non-invasive and non-destructive (including non-target taxa) alternative. In fact, advancements including DNA collections the surface of organisms (e.g., DNA from leaf surfaces; Valentin et al., 2020), preventing the scarification or sacrifice of organisms, further highlights the non-destructive advantages of eDNA for elucidating complex PAI 


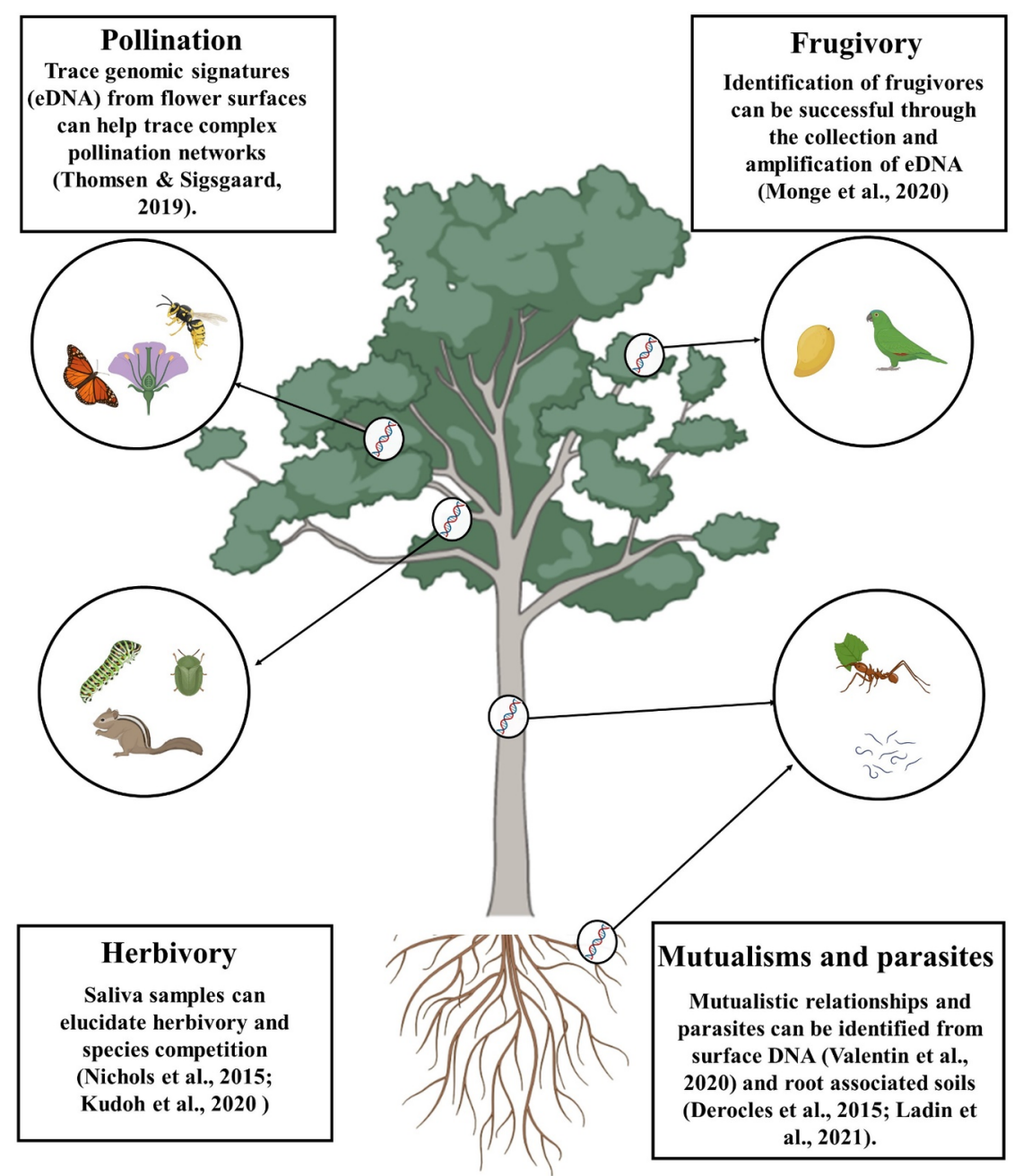

Figure 1: Biological signatures in the form of eDNA or eRNA can be detected from plants noninvasively to trace out complex interactions. Illustration presents hypothetical examples of PAI (e.g., pollination, herbivory, frugivory, and mutualism) including representative examples in the literature.

\section{Current advancements in eDNA for the study of PAI}

Although still in its infancy, species-specific assays as well as metabarcoding of eDNA have demonstrated great application for understanding PAI in nature (see Table 1 and Table 2). Here we summarize the ways in which various PAI (i.e., pollination, predation and mutualism) can be documented for whole communities using the collection and analysis of eDNA.

Pollination is one of the most well studied PAI since it brings about gene recombination (Faegri \& Pijl, 1979), and exemplifies myriad central ecological and evolutionary principles and theories. In pollinator PAI, the loss of even a singular plant species can trigger rapid extinction of specialist pollinators, which is also of serious ecological and economical concern (Klein et al., 2007; NEA, 2011). To date, researchers have taken advantage of eDNA-based analysis to detect and monitor pollinators, their feeding preferences, species-specificity, niche separation, and coevolution (Table 1). In particular, eDNA metabarcoding of honey samples has been 
demonstrated to detect more taxa than conventional methods, where species-specificity (i.e., identification of generalists and specialists), foraging activity, and complex interactions have been analysed rapidly and cost-effectively (Hawkins et al., 2015; De Vere et al., 2017). Interestingly, eDNA from honey samples can also help to identify other entomological signatures within forests or agricultural fields, such as those from plant-sucking insects whose "honeydew" droplets are incorporated in honey reserves (Utzeri et al., 2018). Bovo et al. (2018) further demonstrated the utility of eDNA tools to understand the micro-ecosystem within honey bee colonies by detecting the eDNA signals from five distinct groups (i.e., arthropods, plants, fungi, bacteria, viruses). Although not strictly PAI, this study further exemplifies eDNA-based methods as a potential avenue for information regarding wildlife diseases and epidemics.

While complex pollinator networks are typically difficult to identify and discriminate using conventional sampling, eDNA collections taken directly from flowers or leaves have further shown promise to gain an indepth understanding of dynamic pollinator and herbivore interactions (Thomsen \& Sigsgaard., 2019; Kudoh et al., 2020). For example, Thomsen \& Sigsgaard (2019) detected eDNA signatures from 135 arthropod species originating from diverse ecological groups deposited on wildflowers (e.g., pollinators, parasitoids, gall inducers, predators and phytophagous species), and suggested potential use of eDNA approaches for estimating interactive species compositions, deducing the effects of environmental change, and monitoring endangered, cryptic and invasive species (Thomsen \& Sigsgaard, 2019).

Understanding the complex interactions between frugivores and plants also remains a challenge, but recent strides using eDNA traces to detect specific interactions of fruit-eaters have now made this prospect more convenient. For example, Monge et al. (2020) successfully amplified salivary eDNA of frugivorous birds (Ara macao) from tropical almond (Terminalia catappa) fruit remains. Albeit with limited success, this study further provided proof-of-concept for the use of eDNA in non-destructive sex identification, potentially ushering in a new frontier for studying sex-specific differences in PAI.

Herbivores often prefer a certain plant or group of species, which may cause shifts in plant composition. Thus, it would be beneficial to identify the diversity of plant taxa eaten by particular herbivores and the number of herbivores visiting focal plants. For herbivory, eDNA-based methods have been shown to detect large numbers of taxa more efficiently than other sampling methodologies (e.g., microscopic analysis of fecal sample, bulk DNA metabarcoding; Tournayre et al., 2021). In fact, eDNA metabarcoding has also been applied to understand the dietary overlap and competition among domestic and wild herbivores (ter Schure et al., 2021). Notably, sampling matter may be a restricted application to large organisms with detectable faecal deposits. To overcome this limitation, salivary samples can be collected to identify herbivores that have fed upon specific plants, even from small taxa (e.g., from browsed twigs, Valentin et al., 2020; or leaves, Nichols et al., 2012). For example, Nichols et al. (2015) applied eDNA analysis across a large forest landscape, proving the utility of this method for studying cryptic browsing behaviour. Salivary eDNA signatures can also be used to assess foraging preferences and niche separation among species (e.g., Van Beeck Calkoen et al. 2019). Impressively, salivary eDNA signals from insect herbivores within mesocosms have also shown a positive correlation between rim length (i.e., total outer edge) of feeding marks and eDNA concentration, implying eDNA signatures may be able to quantitatively delineate the amount of herbivory (Kudoh et al., 2020).

Detecting plant-pathogen/parasite interactions through eDNA has also recently become possible. Derocles et al. (2015) for example, successfully amplified trace DNA from plants-leaf miners-parasitoid interactions and Thomsen \& Sigsgaard (2019) detected numerous phytophagous species, parasitoids, gall inducers, and predator insects through the metabarcoding of flowers. Although in these studies non-target taxa were used to isolate eDNA, this also can be done in a complete non-destructive manner using newly developed surface-sampling methods (see Valentin et al. 2020). Cumulatively, these studies provide a foundation for detecting antagonistic and cryptic plant-arthropod interactions with applications for disease monitoring and pest management.

Mutualistic relationships between plants and animals (e.g., insects and nematodes) assist plant growth and development, and these relationships can also be studied effectively through eDNA analysis (Ladin et al., 
2021). For example, Rasmussen et al. (2021) used eDNA metabarcoding to explore how the diversity of fungi and arthropods were affected by different agricultural management practices. For a more historical perspective of mutualistic relationships, Gous et al. (2019) applied eDNA methods to investigate pollinator interactions that had occurred over a century ago via ancient honey samples, highlighting eDNA's potential to reveal a time series of species interactions.

Certainly, eDNA methods have advanced our ability to accurately detect the occupancy of species (Deiner et al., 2021), and are highly cost and time-efficient (Qu \& Stewart 2019). Indeed, they have even outperformed conventional methods of biodiversity sampling in several comparisons (McElroy et al. 2020; Fediajevaite et al. 2021), including their ability to capture increased taxonomic diversity compared to conventional methods which can be applicable for large-scale monitoring (Macher et al., 2018). Thus, eDNA-based methods have gradually overcome some limitations associated with conventional monitoring techniques (e.g., field identifications). Perhaps most importantly for the assessment of ecological integrity and functionality, eDNA has the ability to detect entire communities rapidly.

\section{Current limitations}

There remains a need to understand current limitations of eDNA analysis, especially when it pertains to PAI detection and interpretation. Limitations are spread out among each step of the collection-analysisinterpretation process (Figure 2). The existing limitations of this method are:

(I) The complex, and often idiosyncratic, ecology of eDNA. In effect, practitioners may sample different sources of eDNA (cellular, extracellular, extra-organismal, etc.) (Stewart, 2019; Rodriguez-Ezpeleta et al., 2021), which may lead to different PAI interpretations. For example, pollen and spores (extra organismal DNA) are ubiquitous in the atmosphere, travel long distances (through wind or water), and contain adaptations to persist dormant stages for long periods of time. These, when settled and collected on non-targeted and non-interacting organisms, can lead to misinterpretation. Alternatively, extracellular DNA and cellular DNA are generally specific to places where organisms recently moved and are subject to easy degradation. Thus, clear differentiation of their behavior may help to draw more precise conclusions.

(II) The production and release of eDNA into the environment can also occur at different rates, where eDNA concentration can depend on many variables such as life stage, metabolic activity, or breeding season (Stewart, 2019). What's more, production rate of eDNA is most likely influenced by species interactions themselves (e.g., competition between/among species) (Stewart, 2019). In fact, mixed-species populations have been shown to increase eDNA production rates when housed together compared to single species populations (Sassoubre et al., 2016). Beside the aforementioned characteristics, the persistence of eDNA (Barnes \& Turner, 2016; Deiner et al., 2017; Kudoh et al., 2020), and its transport in and between environmental media (air, water, soil) should also be considered (Barnes \& Turner, 2016; Lacoursière-Roussel \& Deiner, 2021), especially given that these parameters have yet to be standardized for many taxa.

(III) Translating eDNA quantification metrics to organismal abundance has been controversial (Marshall et al., 2021), although recent research has advanced the possibility of absolute quantification (Tillotson et al. 2018; Hoshino et al., 2021) and even predicting dispersion time of eDNA within the environment (Marshall et al., 2021).

(IV) A universal limitation to any genetic-based species identification reliant on databases, is certainly missing species sequences, sequencing error, cloning vector contamination, and the redundancy of data (Singh, 2015). These issues may cause species misidentification which may also lead to the failure in decrypting accurate PAI (Sheppard et al., 2005; Roslin \& Majaneva, 2016).

(V) As eDNA methods sometimes struggle with low detection rate, more comparisons are needed between eDNA and conventional surveys (e.g., camera, malaise traps) for translation of results and inferences between these different methods.

(VI) The detection of niche partitioning using eDNA-based methods is only just beginning (ter Schure et 
al., 2021) and fine-scale partitioning (e.g, different herbivory behaviour on the same plant) may be difficult with current eDNA analysis techniques.

(VII) Unsurprisingly, and similar to conventional approaches, eDNA methods also encounter some technical field and laboratory challenges. This is often because eDNA samples frequently contain PCR inhibitors thereby further reducing already low DNA concentrations (McKee et al., 2015). Besides this, false-positive and false-negative detections are also a matter of concern.

(VIII) Laboratory protocols, including the method of standardization, is directly dependent on sampling procedures, sample quality, environmental factors, and molecular markers design. Although recent studies show evidence of overcoming some technical limitations, such as primer development; chloroplast and nuclear primer for plants (rbcL, matK, trnH-psbA, ITS2, etc.), group specific primers for animals (MiFish, MiBird, etc), protocol standardization, and removing the barrier of inhibitors (Burian et al., 2021), collection and analysis optimization may still be required. Mitochondrial COI is the most common universal barcode for animals demonstrating good species discrimination (Che et al., 2012), but in plants, no single universal barcode provides suitable taxonomic resolution (Jones et al., 2021). For plants, multiple primers from two primary plastid regions in the chloroplast (e.g., rbcl and matK), frequently combined with nuclear regions (e.g., ITS2), have been used for barcoding but none of these have been found to be suitable across all species due to rampant introgressive hybridization and polyploidy (Jones et al., 2021). 


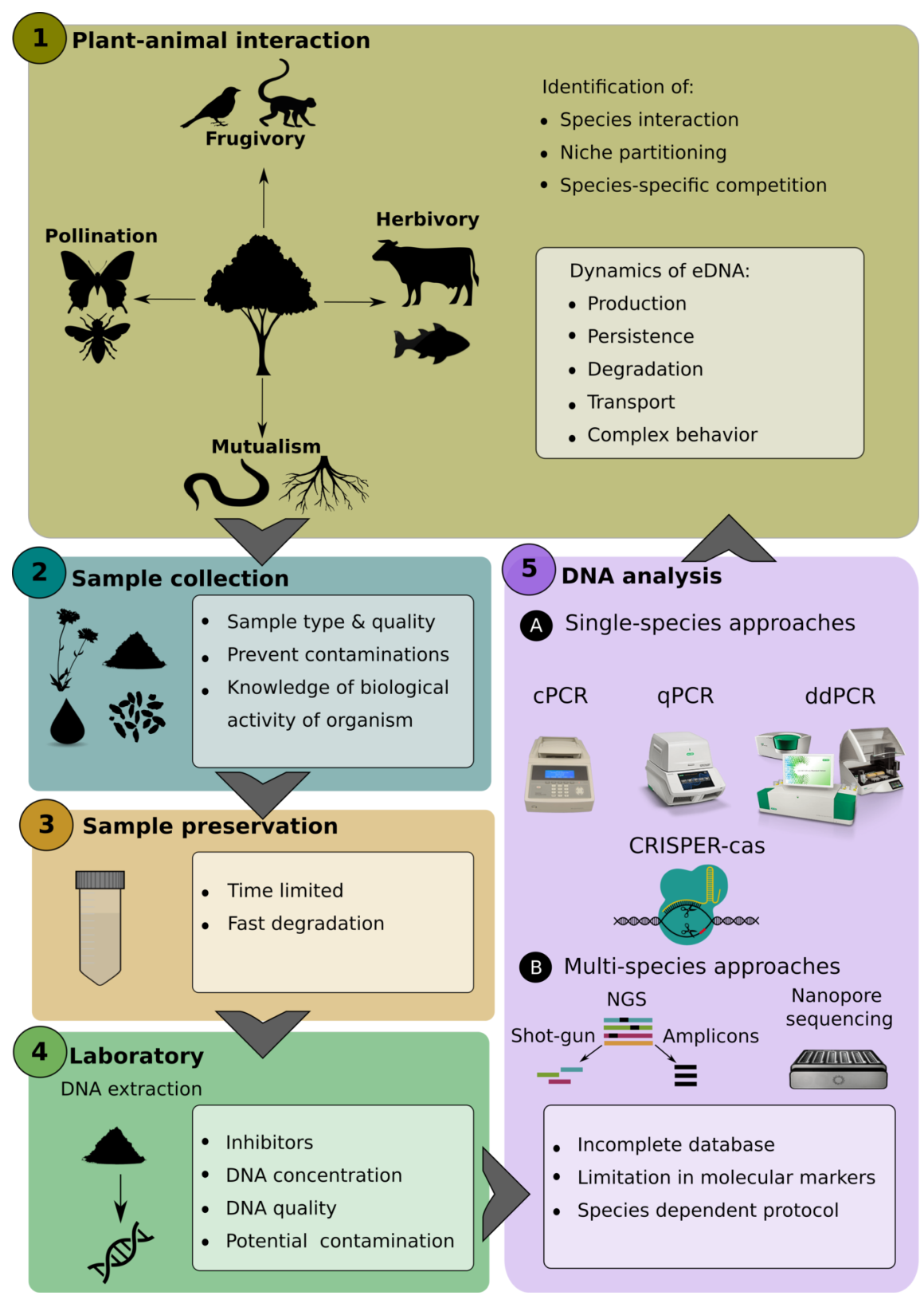

Figure 1: Figure 2: This is Workflow including potential limitations (inserted box) in each step for eDNA analysis in Plant-animal interactions (PAI) detection (cPCR $=$ conventional PCR, qPCR = quantitative PCR, ddPCR = droplet digital PCR, CRISPR-cas = Clustered Regularly Interspaced Short Palindromic Repeats- CRISPR-associated protein, NGS= next generation sequencing). a caption

Table 1: Plant-animal interaction (PAI) studies using eDNA methods between 2009 and 2021. Key expressions were used for study inclusion via Google Scholar: "eDNA and plant-animal interactions", "eDNA and herbivory", "eDNA and pollination", "eDNA and symbiosis", "eDNA 
and predation", "eDNA and parasitism" and "fecal DNA".

\begin{tabular}{|c|c|c|c|}
\hline $\begin{array}{l}\text { Types of PAI } \\
\text { Positive }\end{array}$ & Organisms involved & Applications & Reference \\
\hline Mutualism /Symbiosis & Arthropods and plants & $\begin{array}{l}\text { Sustainable agricultural } \\
\text { methods }\end{array}$ & Rasmussen et al. 2021 \\
\hline \multirow[t]{5}{*}{ Pollination } & Arthropods and plants & $\begin{array}{l}\text { Environmental integrity } \\
\text { and pest management }\end{array}$ & $\begin{array}{l}\text { Thomsen \& Sigsgaard, } \\
2019\end{array}$ \\
\hline & Bats and plants & $\begin{array}{l}\text { Identification of } \\
\text { plant-feeding behavior, } \\
\text { pollen transport, seed } \\
\text { dispersions }\end{array}$ & $\begin{array}{l}\text { Edwards et al. 2019; Bell } \\
\text { et al. } 2021\end{array}$ \\
\hline & Honey bees and plants & $\begin{array}{l}\text { Pollinator-plant } \\
\text { preference and } \\
\text { interactions }\end{array}$ & $\begin{array}{l}\text { Hawkins et al. 2015; } \\
\text { Keller et al. 2015; Bovo } \\
\text { et al. 2018; De Vere et al. } \\
\text { 2017; Milla et al. 2021; } \\
\text { Oliver et al. } 2021\end{array}$ \\
\hline & Insects and plants & $\begin{array}{l}\text { Pollen-transport } \\
\text { interactions; ecosystem } \\
\text { monitoring }\end{array}$ & $\begin{array}{l}\text { Pornon et al. } 2016 \\
\text { Utzeri et al. } 2018 \\
\text { Baksay et al. } 2020\end{array}$ \\
\hline & Moths and plants & $\begin{array}{l}\text { Identification of } \\
\text { plant-feeding behavior } \\
\text { and pollen transport } \\
\text { networks }\end{array}$ & $\begin{array}{l}\text { Chang et al. 2018; } \\
\text { Macgregor et al. } 2019\end{array}$ \\
\hline Frugivory & Birds and plants & $\begin{array}{l}\text { Species interaction and } \\
\text { potential use in } \\
\text { population genetics }\end{array}$ & Monge et al. 2020 \\
\hline \multicolumn{4}{|l|}{ Antagonistic } \\
\hline Parasite/parasitoid & Parasitoid and plants & $\begin{array}{l}\text { Identification of } \\
\text { plant-parasitoids } \\
\text { interaction, } \\
\text { environmental integrity } \\
\text { and pest management }\end{array}$ & $\begin{array}{l}\text { Derocles et al. } 2015 \text {; } \\
\text { Thomsen \& Sigsgaard, } \\
2019\end{array}$ \\
\hline \multirow[t]{8}{*}{ Predation/Herbivory } & Deers and plants & $\begin{array}{l}\text { Forest management; } \\
\text { foraging behaviors; } \\
\text { dietary assessment for } \\
\text { conservation purposes }\end{array}$ & $\begin{array}{l}\text { van Beeck Calkoen et al. } \\
\text { 2019; Iacolina et al. } 2020 \text {; } \\
\text { Nakahama et al. } 2021\end{array}$ \\
\hline & $\begin{array}{l}\text { European bison and } \\
\text { plants }\end{array}$ & Dietary assessment & Kowalczyk et al. 2019 \\
\hline & Gazelle and plants & $\begin{array}{l}\text { Dietary assessment for } \\
\text { conservation purposes }\end{array}$ & Ait Baamrane et al. 2012 \\
\hline & Grouse and plants & $\begin{array}{l}\text { Dietary assessment for } \\
\text { conservation purposes }\end{array}$ & Chua et al. 2021 \\
\hline & $\begin{array}{l}\text { Idaho ground squirrel } \\
\text { and plants }\end{array}$ & $\begin{array}{l}\text { Dietary assessment for } \\
\text { conservation purposes }\end{array}$ & Goldberg et al. 2020 \\
\hline & Insects and plants & $\begin{array}{l}\text { Mesocosm validation of } \\
\text { insect-plant interactions }\end{array}$ & Kudoh et al. 2020 \\
\hline & Italian hare and plants & $\begin{array}{l}\text { Dietary assessment for } \\
\text { conservation purposes }\end{array}$ & Buglione et al. 2018 \\
\hline & Lambs and plants & $\begin{array}{l}\text { Dietary assessment and } \\
\text { feeding selectivity }\end{array}$ & Pegard et al. 2009 \\
\hline
\end{tabular}




\begin{tabular}{|c|c|c|}
\hline Lemmings and plants & $\begin{array}{l}\text { Dietary assessment and } \\
\text { foraging behaviors }\end{array}$ & Soininen et al. 2017 \\
\hline Lemur and plants & $\begin{array}{l}\text { Dietary assessment for } \\
\text { conservation purposes }\end{array}$ & Quéméré et al. 2013 \\
\hline Mammals and plants & $\begin{array}{l}\text { Dietary assessment, } \\
\text { foraging behaviors, } \\
\text { trophic interactions and } \\
\text { niche partitioning }\end{array}$ & $\begin{array}{l}\text { Kartzinel et al. } 2015 ; \\
\text { Meyer et al. 2020; } \\
\text { Boukhdoud et al. } 2021 \text {; } \\
\text { ter Schure et al. } 2021\end{array}$ \\
\hline Moose and plants & $\begin{array}{l}\text { Dietary assessment for } \\
\text { conservation purposes }\end{array}$ & Iacolina et al. 2020 \\
\hline Mouse and plants & $\begin{array}{l}\text { Dietary assessment for } \\
\text { conservation purposes }\end{array}$ & Iwanowicz et al. 2016 \\
\hline Nematodes and plants & $\begin{array}{l}\text { Dietary assessment and } \\
\text { study the impact of } \\
\text { climatic variation }\end{array}$ & Pitteloud et al. 2020 \\
\hline Orthoptera and plants & $\begin{array}{l}\text { Dietary assessment and } \\
\text { study the impact of } \\
\text { climatic variation }\end{array}$ & Pitteloud et al. 2020 \\
\hline Tapir and plants & $\begin{array}{l}\text { Dietary assessment and } \\
\text { trophic interactions }\end{array}$ & Hilbert et al. 2013 \\
\hline Turtles and lotus roots & $\begin{array}{l}\text { Dietary assessment and } \\
\text { feeding activity }\end{array}$ & Koizumi et al. 2016 \\
\hline Ungulates and plants & $\begin{array}{l}\text { Dietary assessment, } \\
\text { foraging behaviors, and } \\
\text { ecological interactions }\end{array}$ & $\begin{array}{l}\text { Nichols et al. } 2012 \text {; } \\
\text { Nichols et al. } 2015\end{array}$ \\
\hline $\begin{array}{l}\text { Woodland caribou and } \\
\text { plants }\end{array}$ & $\begin{array}{l}\text { Dietary assessment for } \\
\text { conservation purposes }\end{array}$ & Newmaster et al. 2013 \\
\hline
\end{tabular}

\section{Future perspectives}

The advent of eDNA quantification has offered an exciting but as yet untapped future in discovering the complex and dynamic pattern of species interactions. Implementation of eDNA analysis has thus far proved helpful in studying rapid changes in ecosystems (e.g., diversity and species interaction changes due to anthropogenic pressure; DiBattistaet al., 2020) and may also advance our understanding of the effect of habitat fragmentation, sudden natural calamities, or rapid climatic changes (Bartlett et al., 2016). Environmental DNA may even demonstrate utility in assessing how range or phenological shifts via climate change alter PAI. For example, will climate change maintain or dismantle entire networks of integrated species? We envision research into the congruence or discordance of plant flowering time and their pollinators. Certainly, the ease of collecting eDNA is a major advantage to questions requiring successive time series data (e.g., coevolution, or niche separation) and we expect this to be a major avenue for investigation in the near future.

The ease and rapidity of eDNA analysis particularly lends itself to the monitoring of invasive species (Kim et al., 2018), and here too eDNA methodology may illuminate how invasive species change complex species interactions on an ecosystem scale. While it is true that invasive species, at least initially, add to the net biodiversity of a region, will these species also add to species-interactions, weaken specialized species interactions, or break them altogether? Here, eDNA analysis may be especially important for these assessments early during colonization events, when invasive species removal and thus their impact to well-established species interactions, may be circumvented.

Recent methodological developments to collect and extract environmental RNA (eRNA) might also be leveraged to understand changes of gene expression with physical and biological pressure (functional genomics; Tsuri et al., 2021), with possibilities of expansion into ecological epigenetics, ecosystem health, func- 
tional metagenomics, population-level inference, or even the interface of species-species interactions (e.g., Stewart \& Taylor, 2020; Veilleux et al., 2021). Unlike eDNA, eRNA can go beyond species and PAI quantification, such as understanding life histories, ages, metabolic activities, physiological conditions and health of interacting organisms. Functional information of a species, population or community and their functional genes can be detected from mRNA profiling, or miRNA for studying the health of organisms. Furthermore, the short persistence time of eRNA and resulting low concentration within the environment may help to avoid false positive results and even potentially provide an estimate for the relative time of eDNA deposition and thus organismal origin (Marshall et al., 2021). However, to date detection methods for eRNA are not yet well established, lack broad validation in the field, and insufficient reference data may raise concern.

\section{Conclusions}

In the context of global biodiversity decline where ecosystems are under heavy stress and subjected to rapid changes, it is critical to increase our knowledge of species interactions to support the restoration and conservation of ecosystems effectively. Threats to species and ecosystem integrity are often assessed in terms of habitat loss, overharvesting, or over-predation (Kerr \& Deguise, 2004). Yet, populations may also decline through successive loss of species interactions (Valiente-Banuet et al., 2015; Simmons et al., 2020) and studying species in isolation may limit our full understanding of the changes and threats to entire ecosystem of interacting species (Roslin \& Majaneva, 2016). In fact, positive and antagonistic interactions synergically work to maintain the stability, health, and function of an ecosystem, demanding a fast, reliable and non-invasive/destructive approach. Currently, eDNA-based methods exhibit accurate information about species-specificity, community dynamics and ecological networks. Although to date there remains a limited number of investigations using eDNA to critically assess and identify PAI, we propose eDNA methods to herald a revolutionary era for studying complex and cryptic ecological links in nature.

\section{Acknowledgments}

The authors would like to thank the Ministry of Science and Technology (Taiwan) for financial support (MOST 109-2811-M-194-502; MOST 108-2811-M-194-510).

\section{Conflict of interest}

The authors declare no conflict of interest.

\section{Data Availability Statement}

Data sharing not applicable to this article as no datasets were generated or analysed during the current study.

\section{Author contribution}

P.B. conceived of the review; P.B., K.A.S., C.M.A, I.V.B., C.Y.C., H.V., and S.S. prepared the first draft and revised the manuscript. All authors gave extensive edits and revised the manuscript, from conception to final draft. P.B., and H.V., prepared the figure with input from all authors; I.V.B., prepared the table with input from all authors.

\section{References}

Ait Baamrane, M.A., Shehzad, W., Ouhammou, A., Abbad, A., Naimi, M., Coissac, E., Taberlet, P., \& Znari, M. (2012). Assessment of the food habits of the Moroccan dorcas gazelle in M'Sabih Talaa, west central Morocco, using the trn L approach. PLoS One, 7(4), 35643.https://doi.org/10.1371/journal.pone.0035643.

Allwood, J.S., Fierer, N., \& Dunn, R.R. (2020). The future of environmental DNA in forensic science. Applied and Environmental Microbiology, 86(2), 01504-19.https://doi.org/10.1128/AEM.01504-19.

Barnes, M. A., \& Turner, C. R. (2016). The ecology of environmental DNA and implications for conservation genetics. Conservation Genetics, 17(1), 1-17.https://doi.org/10.1007/s10592-015-0775-4. 
Barnes, M.A., Brown, A.D., Daum, M.N., de la Garza, K.A., Driskill, J., Garrett, K., Goldstein, M.S., Luk, A., Maguire, J.I., Moke, R., Ostermaier, E.M., Sanders, Y.M., Sandhu, T., Stith, A., \& Suresh, V.V. (2020). Detection of the amphibian pathogens chytrid fungus (Batrachochytrium dendrobatidis) and ranavirus in West Texas, USA, using environmental DNA. Journal of Wildife Diseases, 56(3), 702706.https://doi.org/10.7589/2019-08-212.

Bartlett, L.J., Newbold, T., Purves, D.W., Tittensor, D.P., \& Harfoot, M.B. (2016). Synergistic impacts of habitat loss and fragmentation on model ecosystems. Proceedings of the Royal Society B: Biological Sciences, 283(1839), 20161027.https://doi.org/10.1098/rspb.2016.1027.

Bovo, S., Ribani, A., Utzeri, V. J., Schiavo, G., Bertolini, F., \& Fontanesi, L. (2018). Shotgun metagenomics of honey DNA: Evaluation of a methodological approach to describe a multi-kingdom honey bee derived environmental DNA signature. PloS One, 13(10), e0205575.https://doi.org/10.1371/journal.pone.0205575.

Buglione, M., Maselli, V., Rippa, D., de Filippo, G., Trapanese, M., \& Fulgione, D. (2018). A pilot study on the application of DNA metabarcoding for non-invasive diet analysis in the Italian hare. Mammalian Biology, 88, 31-42.https://doi.org/10.1016/j.mambio.2017.10.010.

Burian, A., Mauvisseau, Q., Bulling, M., Domisch, S., Qian, S., \& Sweet, M. (2021). Improving the reliability of eDNA data interpretation. Molecular Ecology Resources, 21(5), 1422-1433.https://doi.org/10.1111/17550998.13367 .

Castagneyrol, B., Bonal, D., Damien, M., Jactel, H., Meredieu, C., Muiruri, E.W., \& Barbaro, L. (2017). Bottom-up and top-down effects of tree species diversity on leaf insect herbivory. Ecology and Evolution, 7(10), 520-3531.https://doi.org/10.1002/ece3.2950.

Chama, L., Berens, D.G., Downs, C.T., \& Farwig, N. (2013). Habitat characteristics of forest fragments determine specialisation of plant-frugivore networks in a mosaic forest landscape. PloS One, 8(1), e54956.https://doi.org/10.1371/journal.pone.0054956.

Che, J., Chen, H.M., Yang, J.X., JIN, J.Q., Jiang, K.E., Yuan, Z.Y., Murphy, R.W. \& Zhang, Y.P. (2012). Universal COI primers for DNA barcoding amphibians. Molecular Ecology Resources, 12(2), 247-258. https://doi.org/10.1111/j.1755-0998.2011.03090.x.

Chua, P. Y., Lammers, Y. Y., Menoni, E., Ekrem, T., Bohmann, K., Boessenkool, S., \& Alsos, I. G. (2021). Molecular dietary analyses of western capercaillies (Tetrao urogallus) reveal a diverse diet. bioRxiv.https://doi.org/10.1101/2021.03.08.434346.

Clare, E.L. (2014). Molecular detection of trophic interactions: emerging trends, distinct advantages, significant considerations and conservation applications. Evolutionary Applications, 7(9), 11441157.https://doi.org/10.1111/eva.12225.

Colles, A., Liow, L.H., \& Prinzing, A. (2009). Are specialists at risk under environmental change? Neoecological, paleoecological and phylogenetic approaches. Ecology Letters, 12(8), 849863.https://doi.org/10.1111/j.1461-0248.2009.01336.x.

D'Alessandro, S., \& Mariani, S. (2021). Sifting environmental DNA metabarcoding data sets for rapid reconstruction of marine food webs. Fish and Fisheries.https://doi.org/10.1111/faf.12553.

De Vere, N., Jones, L.E., Gilmore, T., Moscrop, J., Lowe, A., Smith, D., Hegarty, M.J., Creer, S., \& Ford, C.R. (2017). Using DNA metabarcoding to investigate honey bee foraging reveals limited flower use despite high floral availability. Scientific Reports, 7(1), 1-10.https://doi.org/10.1038/srep42838.

Deiner, K., Bik, H.M., Mächler, E., Seymour, M., Lacoursière-Roussel, A., Altermatt, F., Creer, S., Bista, I., Lodge, D.M., De Vere, N., \& Pfrender, M.E. (2017). Environmental DNA metabarcoding: Transforming how we survey animal and plant communities. Molecular Ecology, 26(21), 5872-5895. https://doi.org/10.1111/mec.14350. 
Deiner, K., Yamanaka, H., \& Bernatchez, L. (2021). The future of biodiversity monitoring and conservation utilizing environmental DNA. Environmental DNA, 3(1), 3-7.https://doi.org/10.1002/edn3.178.

Derocles, S.A., Evans, D.M., Nichols, P.C., Evans, S.A., \& Lunt, D.H. (2015). Determining plant-leaf miner-parasitoid interactions: a DNA barcoding approach. PloS One, 10(2), e0117872. https://doi.org/ 10.1371/journal. pone. 0117872 .

Derycke, S., De Ley, P., Tandingan De Ley, I., Holovachov, O., Rigaux, A. \& Moens, T. (2010). Linking DNA sequences to morphology: cryptic diversity and population genetic structure in the marine nematode Thoracostoma trachygaster (Nematoda, Leptosomatidae). Zoologica Scripta, 39(3), 276-289. https://doi.org/10.1111/j.1463-6409.2009.00420.x.

DiBattista, J.D., Reimer, J.D., Stat, M., Masucci, G.D., Biondi, P., De Brauwer, M., Wilkinson, S.P., Chariton, A.A., \& Bunce, M. (2020). Environmental DNA can act as a biodiversity barometer of anthropogenic pressures in coastal ecosystems. Scientific Reports, 10(1), 1-15.https://doi.org/10.1038/s41598-020-64858-9.

Echevarria-Machado, I., Sanchez-Cach, L.A., Hernandez-Zepeda, C., Rivera-Madrid, R., \& MorenoValenzuela, O.A. (2005). A simple and efficient method for isolation of DNA in high mucilaginous plant tissues. Molecular Biotechnology, 31(2), 129-135.https://doi.org/10.1385/MB:31:2:129.

Ellis, A.G., \& Johnson, S.D. (2012). Lack of floral constancy by bee fly pollinators: implications for ethological isolation in an African daisy. Behavioral Ecology, 23(4), 729-734.https://doi.org/10.1093/beheco/ ars019.

Evans, D.M. \& Kitson, J.J. (2020). Molecular ecology as a tool for understanding pollination and other plantinsect interactions. Current opinion in insect science, 38, 26-33. https://doi.org/10.1016/j.cois.2020.01.005.

Evans, D.M., Kitson, J.J., Lunt, D.H., Straw, N.A., \& Pocock, M.J. (2016). Merging DNA metabarcoding and ecological network analysis to understand and build resilient terrestrial ecosystems. Functional Ecology, 30(12), 1904-1916.https://doi.org/10.1111/1365-2435.12659.

Faegri, K., \& Pijl, V. D. L. 1979. The principles of pollination ecology (64, p-6-7). (3d rev. ed.) Oxford; New York: Pergamon Press.

Fediajevaite, J., Priestley, V., Arnold, R., \& Savolainen, V. (2021). Meta-analysis shows that environmental DNA outperforms traditional surveys, but warrants better reporting standards. Ecology and Evolution, 11(9), 4803-4815.https://doi.org/10.1002/ece3.7382.

Ficetola, G.F., Miaud, C., Pompanon, F., \& Taberlet, P. (2008). Species detection using environmental DNA from water samples. Biology Letters 4(4), 423-425.https://doi.org/10.1098/rsbl.2008.0118.

Garcia-Robledo, C., Erickson, D.L., Staines, C.L., Erwin, T.L., \& Kress, W.J. (2013). Tropical plantherbivore networks: reconstructing species interactions using DNA barcodes. PLoS One, 8(1), e52967.https: //doi.org/10.1371/journal. pone.0052967.

Gogarten, J.F., Hoffmann, C., Arandjelovic, M., Sachse, A., Merkel, K., Dieguez, P., Agbor, A., Angedakin, S., Brazzola, G., Jones, S., Langergraber, K.E., Lee, K., Marrocoli, S., Murai, M., Sommer, V., Kuhl, H., Leendertz, F.H., \& Calvignac-Spencer, S. (2020). Fly-derived DNA and camera traps are complementary tools for assessing mammalian biodiversity. Environmental DNA 2(1), 6376.https://doi.org/10.1002/edn3.46.

Goldberg, A.R., Conway, C.J., Tank, D.C., Andrews, K.R., Gour, D.S., \& Waits, L.P. (2020). Diet of a rare herbivore based on DNA metabarcoding of feces: Selection, seasonality, and survival. Ecology and Evolution, 10(14), 7627-7643.https://doi.org/10.1002/ece3.6488.

Gous, A., Swanevelder, D.Z., Eardley, C.D., \& Willows-Munro, S. (2019). Plant-pollinator interactions over time: Pollen metabarcoding from bees in a historic collection. Evolutionary Applications, 12(2), 187197.https://doi.org/10.1111/eva.12707. 
Guenay, Y., Trager, H., Glarcher, I., Traugott, M., \& Wallinger, C. (2021). Limited detection of secondarily consumed plant food by DNA-based diet analysis of omnivorous carabid beetles. Environmental DNA, 3(2), 426-434.https://doi.org/10.1002/edn3.128.

Hawkins, J., de Vere, N., Griffith, A., Ford, C.R., Allainguillaume, J., Hegarty, M.J., Baillie, L., \& AdamsGroom, B. (2015). Using DNA metabarcoding to identify the floral composition of honey: a new tool for investigating honey bee foraging preferences. PLoS One, 10(8), e0134735.https://doi.org/10.1371/ journal.pone. 0134735 .

Herrera, C.M. \& Pellmyr, O. eds. (2009). Plant animal interactions: an evolutionary approach. John Wiley \& Sons.

Hilbert, F., Taberlet, P., Chave, J., Scotti-Saintagne, C., Sabatier, D., \& Richard-Hansen, C. (2013). Unveiling the diet of elusive rainforest herbivores in next generation sequencing era? The tapir as a case study. PLoS One, 8(4), e60799.https://doi.org/10.1371/journal.pone.0060799.

Hoshino, T., Nakao, R., Doi, H., \& Minamoto, T. (2021). Simultaneous absolute quantification and sequencing of fish environmental DNA in a mesocosm by quantitative sequencing technique. Scientific Reports, 11(1), 1-9.https://doi.org/10.1038/s41598-021-83318-6.

IPBES. (2019). Global assessment report on biodiversity and ecosystem services of the Intergovernmental Science-Policy Platform on Biodiversity and Ecosystem Services. E.S. Brondizio, J. Settele, S. Diaz, and H.T. Ngo (eds). IPBES secretariat, Bonn, Germany. 1-56.https://ipbes.net/global-assessment.

Iwanowicz, D.D., Vandergast, A.G., Cornman, R.S., Adams, C.R., Kohn, J.R., Fisher, R.N., \& Brehme, C.S. (2016). Metabarcoding of fecal samples to determine herbivore diets: A case study of the endangered Pacific pocket mouse. PloS One, 11(11), e0165366.https://doi.org/10.1371/journal.pone.0165366.

Jones, L., Twyford, A.D., Ford, C.R., Rich, T.C., Davies, H., Forrest, L.L., Hart, M.L., McHaffie, H., Brown, M.R., Hollingsworth, P.M., \& De Vere, N. (2021). Barcode UK: A complete DNA barcoding resource for the flowering plants and conifers of the United Kingdom. Molecular Ecology Resources, 21(6), 2050-2062. https://doi.org/10.1111/1755-0998.13388.

Kartzinel, T.R., Chen, P.A., Coverdale, T.C., Erickson, D.L., Kress, W.J., Kuzmina, M.L., Rubenstein, D.I., Wang, W., \& Pringle, R.M. (2015). DNA metabarcoding illuminates dietary niche partitioning by African large herbivores. Proceedings of the National Academy of Sciences, 112(26), 80198024.https://doi.org/10.1073/pnas.1503283112.

Kerr, J.T., \& Deguise, I. (2004). Habitat loss and the limits to endangered species recovery. Ecology Letters, 7(12), 1163-1169. https://doi.org/10.1111/j.1461-0248.2004.00676.x.

Kim, P., Kim, D., Yoon, T.J. \& Shin, S. (2018). Early detection of marine invasive species, Bugula neritina (Bryozoa: Cheilostomatida), using species-specific primers and environmental DNA analysis in Korea. Marine environmental research, 139, 1-10. https://doi.org/10.1016/j.marenvres.2018.04.015.

Klein, A.M., Vaissiere, B.E., Cane, J.H., Steffan-Dewenter, I., Cunningham, S.A., Kremen, C., \& Tscharntke, T. (2007). Importance of pollinators in changing landscapes for world crops. Proceedings of the Royal Society B: Biological Sciences, 274(1608), 303-313.https://doi.org/10.1098/rspb.2006.3721.

Koizumi, N., Mori, A., Mineta, T., Sawada, E., Watabe, K., \& Takemura, T. (2016). Exploratory environmental DNA analysis for investigating plant-feeding habit of the red-eared turtle using their feces samples. Jurnal Teknologi, 78(1-2).https://doi.org/10.11113/jt.v78.7253.

Kress, W.J., Garcia-Robledo, C., Uriarte, M., \& Erickson, D.L. (2015). DNA barcodes for ecology, evolution, and conservation. Trends in Ecology 85 Evolution, 30(1), 25-35.https://doi.org/10.1016/j.tree. 2014. 10.008 . 
Kudoh, A., Minamoto, T., \& Yamamoto, S. (2020). Detection of herbivory: eDNA detection from feeding marks on leaves. Environmental DNA, 2(4), 627-634.https://doi.org/10.1002/edn3.113

Lacoursiere-Roussel, A., \& Deiner, K. (2021). Environmental DNA is not the tool by itself. Journal of Fish Biology, 98(2), 383-386.https://doi.org/10.1111/jfb.14177.

Ladin, Z.S., Ferrell, B., Dums, J.T., Moore, R.M., Levia, D.F., Shriver, W.G., D’Amico, V., Trammell, T.L., Setubal, J.C., \& Wommack, K.E. (2021). Assessing the efficacy of eDNA metabarcoding for measuring microbial biodiversity within forest ecosystems. Scientific Reports, 11(1), 1-14.https://doi.org/10.1038/s41598020-80602-9.

Leray, M., Boehm, J.T.,Mills, S.C., \& Meyer, C.P. (2012). Moorea BIOCODE barcode library as a tool for understanding predator-prey interactions: insights into the diet of common predatory coral reef fishes. Coral Reefs 31: 383-388.https://doi.org/10.1007/s00338-011-0845-0.

Leray, M., Meyer, C.P., \& Mills, S.C. (2015). Metabarcoding dietary analysis of coral dwelling predatory fish demonstrates the minor contribution of coral mutualists to their highly partitioned, generalist diet. PeerJ, 3: e1047.https://doi.org/10.7717/peerj.1047.

Luna, P. \& Dattilo, W. (2021). Disentangling plant-animal interactions into complex networks: a multi-view approach and perspectives. In Plant-animal interactions (pp. 261-281). Springer, Cham.

Macgregor, C.J., Kitson, J.J., Fox, R., Hahn, C., Lunt, D.H., Pocock, M.J. \& Evans, D.M. (2019). Construction, validation, and application of nocturnal pollen transport networks in an agro-ecosystem: A comparison using light microscopy and DNA metabarcoding. Ecological Entomology, 44(1), 17-29. https://doi.org/10.1111/een.12674.

Macher, J.N., Vivancos, A., Piggott, J.J., Centeno, F.C., Matthaei, C.D., \& Leese, F. (2018). Comparison of environmental DNA and bulk-sample metabarcoding using highly degenerate cytochrome c oxidase I primers. Molecular Ecology Resources, 18(6), 1456-1468.https://doi.org/10.1111/1755-0998.12940.

Marshall, N.T., Vanderploeg, H.A., \& Chaganti, S.R. (2021). Environmental (e) RNA advances the reliability of eDNA by predicting its age. Scientific Reports, 11(1), 1-11.https://doi.org/10.1038/s41598-021-82205-4.

McElroy, M.E., Dressler, T.L., Titcomb, G.C., Wilson, E.A., Deiner, K., Dudley, T.L., Eliason, E.J., Evans, N.T., Gaines, S.D., Lafferty, K.D., \& Lamberti, G.A. (2020). Calibrating environmental DNA metabarcoding to conventional surveys for measuring fish species richness. Frontiers in Ecology and Evolution, 8, 276.https://doi.org/10.3389/fevo.2020.00276.

McKee, A. M., Spear, S. F., \& Pierson, T. W. (2015). The effect of dilution and the use of a post-extraction nucleic acid purification column on the accuracy, precision, and inhibition of environmental DNA samples. Biological Conservation, 183, 70-76. https://doi.org/10.1016/j.biocon.2014.11.031.

Meyer, J. M., Leempoel, K., Losapio, G., \& Hadly, E. A. (2020). Molecular ecological network analyses: An effective conservation tool for the assessment of biodiversity, trophic interactions, and community structure. Frontiers in Ecology and Evolution, 8, 360.https://doi.org/10.3389/fevo.2020.588430.

Milchunas, D.G., \& Lauenroth, W.K. (1993). Quantitative effects of grazing on vegetation and soils over a global range of environments: Ecological Archives M063-001. Ecological Monographs, 63(4), 327366.https://doi.org/10.2307/2937150.

Monge, O., Dumas, D., \& Baus, I. (2020). Environmental DNA from avian residual saliva in fruits and its potential uses in population genetics. Conservation Genetics Resources, 12(1), 131139.https://doi.org/10.1007/s12686-018-1074-4.

Myers, N. (1990). Mass extinctions: what can the past tell us about the present and the future?. Palaeogeography, Palaeoclimatology, Palaeoecology, 82(1-2), 175-185.https://doi.org/10.1016/S0031-0182(12)80031-9. 
NEA UK. 2011. The UK national ecosystem assessment: Synthesis of the key findings. Cambridge: UNEP-WCMC.https://www.unep-wcmc.org/resources-and-data/the-uk-national-ecosystemassessment-synthesis-of-the-key-findings-and-technical-reports.

Newmaster, S.G., Thompson, I.D., Steeves, R.A., Rodgers, A.R., Fazekas, A.J., Maloles, J.R., McMullin, R.T., \& Fryxell, J.M. (2013). Examination of two new technologies to assess the diet of woodland caribou: video recorders attached to collars and DNA barcoding. Canadian Journal of Forest Research, 43(10), 897-900.https://doi.org/10.1139/cjfr-2013-0108.

Nichols, R.V., Cromsigt, J.P., \& Spong, G. (2015). DNA left on browsed twigs uncovers bite-scale resource use patterns in European ungulates. Oecologia, 178(1), 275-284.https://doi.org/10.1007/s00442-014-3196-z.

Nichols, R.V., KOeNIGSSON, H.E.L.E.N.A., Danell, K., \& Spong, G. (2012). Browsed twig environmental DNA: diagnostic PCR to identify ungulate species. Molecular Ecology Resources, 12(6), 983989.https://doi.org/10.1111/j.1755-0998.2012.03172.x.

Olsen, B.R., Troedsson, C., Hadziavdic, K., Pedersen, R.B., \& Rapp, H.T. (2014). A molecular gut content study of Themisto abyssorum (Amphipoda) from A rctic hydrothermal vent and cold seep systems. Molecular Ecology, 23(15), 3877-3889.https://doi.org/10.1111/mec.12511.

Pacini, E., Viegi, L., \& Franchi, G.G. (2008). Types, evolution and significance of plant-animal interactions. Rendiconti Lincei, 19(1), 75-101.https://doi.org/10.1007/s12210-008-0005-9.

Pawlowski, J., Apotheloz-Perret-Gentil, L. \& Altermatt, F. (2020). Environmental DNA: What's behind the term? Clarifying the terminology and recommendations for its future use in biomonitoring. Molecular Ecology, 29(22), 4258-4264. https://doi.org/10.1111/mec.15643.

Pegard, A., Miquel, C., Valentini, A., Coissac, E., Bouvier, F., Francois, D., Taberlet, P., Engel, E., \& Pompanon, F. (2009). Universal DNA-based methods for assessing the diet of grazing livestock and wildlife from feces. Journal of Agricultural and Food Chemistry, 57(13), 5700-5706.https://doi.org/10.1021/jf803680c.

Piaggio, A.J., Engeman, R.M., Hopken, M.W., Humphrey, J.S., Keacher, K.L., Bruce, W.E., \& Avery, M.L. (2014). Detecting an elusive invasive species: a diagnostic PCR to detect Burmese python in Florida waters and an assessment of persistence of environmental DNA. Molecular Ecology Resources, 14(2), 374380.https://doi.org/10.1111/1755-0998.12180.

Pompanon, F., Deagle, B.E., Symondson, W.O., Brown, D.S., Jarman, S.N., \& Taberlet, P. (2012). Who is eating what: diet assessment using next generation sequencing. Molecular Ecology, 21(8), 19311950.https://doi.org/10.1111/j.1365-294X.2011.05403.x.

Qu, C., \& Stewart, K.A. (2019). Evaluating monitoring options for conservation: comparing traditional and environmental DNA tools for a critically endangered mammal. The Science of Nature, 106(3), 19.https://doi.org/10.1007/s00114-019-1605-1.

Quemere, E., Hibert, F., Miquel, C., Lhuillier, E., Rasolondraibe, E., Champeau, J., Rabarivola, C., Nusbaumer, L., Chatelain, C., Gautier, L., \& Ranirison, P. (2013). A DNA metabarcoding study of a primate dietary diversity and plasticity across its entire fragmented range. PloS One, 8(3), e58971.https://doi.org/10.1371/journal.pone.0058971.

Rasmussen, A. J., Nielsen, M., Mak, S.S., Doring, J., Klincke, F., Gopalakrishnan, S., Dunn, R.R., Kauer, R., \& Gilbert, M.T.P. (2021). eDNA-based biomonitoring at an experimental German vineyard to characterize how management regimes shape ecosystem diversity. Environmental DNA, 3(1), 7082.https://doi.org/10.1002/edn3.131.

Robledo-Arnuncio, J.J., \& Garcia, C. (2007). Estimation of the seed dispersal kernel from exact identification of source plants. Molecular Ecology, 16(23), 5098-5109.https://doi.org/10.1111/j.1365-294X.2007.03427.x. 
Rodriguez-Ezpeleta, N., Morissette, O., Bean, C.W., Manu, S., Banerjee, P., Lacoursiere-Roussel, A., Beng, K.C., Alter, S.E., Roger, F., Holman, L.E. \& Stewart, K.A., Monaghan, M.T., Mauvisseau, Q., Mirimin, L., Wangensteen, O.S., Antognazza, C.M., Helyar, S.J., Boer, H., Monchamp, M., Nijland, R., Abbott, C. L., Doi, H., Barnes, M.A., Leray, M., Hablutzel, P.I., Deiner K. (2021). Trade-offs between reducing complex terminology and producing accurate interpretations from environmental DNA: Comment on "Environmental DNA: What's behind the term?" by Pawlowski et al., (2020). Molecular Ecology.https://doi.org/10.1111/mec.15942.

Roman-Palacios, C., \& Wiens, J.J. (2020). Recent responses to climate change reveal the drivers of species extinction and survival. Proceedings of the National Academy of Sciences, 117(8), 42114217.https://doi.org/10.1073/pnas.1913007117.

Roslin, T., \& Majaneva, S. (2016). The use of DNA barcodes in food web construction-terrestrial and aquatic ecologists unite!. Genome, 59(9), 603-628.https://doi.org/10.1139/gen-2015-0229.

Sargent, R.D., \& Ackerly, D.D. (2008). Plant-pollinator interactions and the assembly of plant communities. Trends in Ecology 83 Evolution, 23(3), 123-130.https://doi.org/10.1016/j.tree.2007.11.003.

Sassoubre, L.M., Yamahara, K.M., Gardner, L.D., Block, B.A., \& Boehm, A.B. (2016). Quantification of environmental DNA (eDNA) shedding and decay rates for three marine fish. Environmental Science $\mathcal{E}$ Technology, 50(19), https://doi.org/10456-10464. 10.1021/acs.est.6b03114.

Schallhart, N., Tusch, M.J., Wallinger, C., Staudacher, K., \& Traugott, M. (2012). Effects of plant identity and diversity on the dietary choice of a soil-living insect herbivore. Ecology, 93(12), 26502657.https://doi.org/10.1890/11-2067.1.

Schirawski, J., \& Perlin, M.H. (2018). Plant-microbe interaction 2017-the good, the bad and the diverse. International Journal of Molecular Sciences, 19, 1374https://doi.org/10.3390/ijms19051374.

Sheppard S.K., Bell J., Sunderland K.D., Fenlon J., Skervin D., \& Symondson W.O.C. (2005). Detection of secondary predation by PCR analyses of the gut contents of invertebrate generalist predators. Molecular Ecology, 14: 4461-4468.https://doi.org/10.1111/j.1365-294X.2005.02742.x.

Sheth, B.P. \& Thaker, V.S. (2017). DNA barcoding and traditional taxonomy: an integrated approach for biodiversity conservation. Genome, 60(7), 618-628. https://doi.org/10.1139/gen-2015-0167

Simmons, B.I., Wauchope, H.S., Amano, T., Dicks, L.V., Sutherland, W.J., \& Dakos, V. (2020). Estimating the risk of species interaction loss in mutualistic communities. PLoS Biology, 18(8), e3000843.https://doi.org/10.1371/journal.pbio.3000843.

Singh, G. B. (2015). Fundamentals of Bioinformatics and Computational Biology. Springer.

Stewart, K., Ma, H., Zheng, J., \& Zhao, J. (2017). Using environmental DNA to assess population-wide spatiotemporal reserve use. Conservation Biology, 31(5), 1173-1182.https://doi.org/10.1111/cobi.12910.

Stewart, K.A. (2019). Understanding the effects of biotic and abiotic factors on sources of aquatic environmental DNA. Biodiversity and Conservation, 28(5), 983-1001.https://doi.org/10.1007/s10531-019-01709-8.

Stewart, K.A., \& Taylor, S.A. (2020). Leveraging eDNA to expand the study of hybrid zones. Molecular Ecology, 29(15), 2768-2776.https://doi.org/10.1111/mec.15514.

Symondson, W.O.C. (2002). Molecular identification of prey in predator diets. Molecular Ecology, 11(4), 627-641.https://doi.org/10.1046/j.1365-294X.2002.01471.x.

Taberlet, P., Bonin, A., Zinger, L., \& Coissac, E. (2018). Environmental DNA: For biodiversity research and monitoring. Oxford University Press.

Taberlet, P., Coissac, E., Hajibabaei, M., \& Rieseberg, L.H. (2012). Environmental DNA. Molecular Ecology, 21(8), 1789-1793.https://doi.org/10.1111/j.1365-294X.2012.05542.x. 
ter Schure, A.T., Pillai, A.A., Thorbek, L., Bhavani Shankar, M., Puri, R., Ravikanth, G., de Boer, H.J., \& Boessenkool, S. (2021). eDNA metabarcoding reveals dietary niche overlap among herbivores in an Indian wildlife sanctuary. Environmental DNA, 3(3), 681-696.https://doi.org/10.1002/edn3.168.

Thomsen, P. F., \& Sigsgaard, E. E. (2019). Environmental DNA metabarcoding of wild flowers reveals diverse communities of terrestrial arthropods. Ecology and Evolution, 9(4), 1665-1679.https://doi.org/ 10.1002/ece3.4809.

Tillotson, M. D., Kelly, R. P., Duda, J. J., Hoy, M., Kralj, J., \& Quinn, T. P. (2018). Concentrations of environmental DNA (eDNA) reflect spawning salmon abundance at fine spatial and temporal scales. Biological Conservation, 220, 1-11.https://doi.org/10.1016/j.biocon.2018.01.030.

Tournayre, O., Leuchtmann, M., Galan, M., Trillat, M., Piry, S., Pinaud, D., Filippi-Codaccioni, O., Pontier, D., \& Charbonnel, N. (2021). eDNA metabarcoding reveals a core and secondary diets of the greater horseshoe bat with strong spatio-temporal plasticity. Environmental DNA, 3(1), 277296.https://doi.org/10.1002/edn3.167.

Tsuri, K., Ikeda, S., Hirohara, T., Shimada, Y., Minamoto, T., \& Yamanaka, H. (2021). Messenger RNA typing of environmental RNA (eRNA): A case study on zebrafish tank water with perspectives for the future development of eRNA analysis on aquatic vertebrates. Environmental DNA, 3(1), 1421.https://doi.org/10.1002/edn3.169.

Utzeri, V.J., Schiavo, G., Ribani, A., Tinarelli, S., Bertolini, F., Bovo, S., \& Fontanesi, L. (2018). Entomological signatures in honey: an environmental DNA metabarcoding approach can disclose information on plant-sucking insects in agricultural and forest landscapes. Scientific Reports, 8(1), 1-13.https: //doi.org/10.1038/s41598-018-27933-w.

Valentin, R.E., Fonseca, D.M., Gable, S., Kyle, K.E., Hamilton, G.C., Nielsen, A.L., \& Lockwood, J.L. (2020). Moving eDNA surveys onto land: Strategies for active eDNA aggregation to detect invasive forest insects. Molecular Ecology Resources, 20(3), 746-755.https://doi.org/10.1111/1755-0998.13151.

Valentini, A., Pompanon, F., \& Taberlet, P. (2009). DNA barcoding for ecologists. Trends in Ecology $\mathcal{G}^{3}$ Evolution, 24(2), 110-117.https://doi.org/10.1016/j.tree.2008.09.011.

Valiente-Banuet, A., Aizen, M.A., Alcantara, J.M., Arroyo, J., Cocucci, A., Galetti, M., Garcia, M.B., Garcia, D., Gomez, J.M., Jordano, P., \& Medel, R. (2015). Beyond species loss: the extinction of ecological interactions in a changing world. Functional Ecology, 29(3), 299-307.https://doi.org/10.1111/1365-2435.12356.

van Beeck Calkoen, S. T., Leigh-Moy, K., Cromsigt, J.P.G.M., Spong, G., Lebeau, L.C., \& heurich, M. (2019). The blame game: Using eDNA to identify species-specific tree browsing by red deer (Cervus elaphus) and roe deer (Capreolus capreolus) in a temperate forest. Forest Ecology and Management, 451, 117483.https://doi.org/10.1016/j.foreco.2019.117483.

Veilleux, H.D., Misutka, M.D., \& Glover, C.N. (2021). Environmental DNA and environmental RNA: current and prospective applications for biological monitoring. Science of The Total Environment, 46891.https://doi.org/10.1016/j.scitotenv.2021.146891.

Wirta, H., Varkonyi, G., Rasmussen, C., Kaartinen, R., Schmidt, N.M., Hebert, P.D.N., Bartak, M., Blagoev, G., Disney, H., Ertl, S., Gjelstrup, P., Gwiazdowicz, D. J., Huldén L., Ilmonen J., Jakovlev J., Jaschhof M., Kahanpää J., Kankaanpää T., Krogh P. H., Labbee R., Lettner C., Michelsen V., Nielsen S. A., Nielsen T. R., Paasivirta L., Pedersen S., Pohjoismäki J., Salmela J., Vilkamaa P., Väre H., von Tschirnhaus M., \& Roslin T. (2016). Establishing a community-wide DNA barcode library as a new tool for arctic research. Molecular Ecology Resources, 16(3), 809-822.https://doi.org/10.1111/1755-0998.12489.

Wirta, H.K., Hebert, P.D.N., Kaartinen, R., Prosser, S.W., Varkonyi, G., \& Roslin, T. (2014). Complementary molecular information changes our perception of food web structure. Proceedings of the National Academy of Sciences, U.S.A., 111, 1885-1890.https://doi.org/10.1073/pnas.1316990111. 
Wirta, H.K., Vesterinen, E.J., Hambäck, P.A., Weingartner, E., Rasmussen, C., Reneerkens, J., Schmidt, N.M., Gilg, O., \& Roslin, T. (2015a). Exposing the structure of an Arctic food web. Ecology and Evolution, 5(17), 3842-3856.https://doi.org/10.1002/ece3.1647.

Wirta, H.K., Weingartner, E., Hambäck, P.A., \& Roslin, T. (2015b). Extensive niche overlap among the dominant arthropod predators of the High Arctic. Basic and Applied Ecology, 16(1), 8692.https://doi.org/10.1016/j.baae.2014.11.003.

Wirth, R., Meyer, S.T., Leal, I.R., \& Tabarelli, M. (2008). Plant herbivore interactions at the forest edge. In Progress in botany (pp. 423-448). Springer, Berlin, Heidelberg.

Xie, Y., Wang, J., Yang, J., Giesy, J.P., Yu, H., \& Zhang, X. (2017). Environmental DNA metabarcoding reveals primary chemical contaminants in freshwater sediments from different land-use types. Chemosphere, 172, 201-209.https://doi.org/10.1016/j.chemosphere.2016.12.117. 